\title{
A origem provincial do Fórum de Trajano
}

Irmina Doneux Santos*

SANTOS, I.D. A origem provincial do Fórum de Trajano. Revista do Museu de Arqueologia e Etnologia, São Paulo, 18: 259-278, 2008.

Resumo: O Fórum de Trajano sempre foi considerado o "ponto alto" do desenvolvimento dos fóruns romanos. Último fórum imperial erguido no centro da Vrbs, durante séculos impressionou os visitantes da cidade, mesmo quando Roma já não era o centro do Império. Até algumas décadas atrás, os estudiosos o consideravam como modelo para os fóruns provinciais, especialmente no Ocidente Europeu. Mas escavações mais recentes trouxeram à luz exemplos de fóruns tripartidos contemporâneos e mesmo anteriores ao de Trajano, derrubando a noção de que este tipo de fórum surgiu em Roma e difundiu-se para o Império. Ele realmente serviu como modelo, mas não como modelo inicial, e sim como o ápice dos fóruns tripartidos, modelo seguido em diversas províncias a partir do século II.

Palavras-chave: Fóruns romanos - Fórum de Trajano - Fóruns Provinciais Ocidentais - Basílica Ulpia - Modelo edilício romano.

\section{Os Fóruns Imperiais}

C s fóruns imperiais, na cidade de Roma, construídos em sucessão, determinaram as formas dos fóruns nas províncias ocidentais. O modelo inicial foi o de César, e o de Augusto seguiu a mesma estrutura básica. Para Léon Homo, "César e Augusto, estes dois grandes empreendedores em matéria de urbanismo, aparecem como os criadores do Fórum imperial" (1971: 344). Mas a grande diferença - a colocação da basílica inserida no corpo dos pórticos que delimitam o espaço do fórum -

$\left({ }^{*}\right)$ Museu de Arqueologia e Etnologia da Universidade de São Paulo; doutoranda em Arqueologia, idoneux@usp.br aparece, em Roma, com Trajano. Esta inovação, porém, não surgiu em Roma, mas exatamente nas províncias ocidentais (Fig. 1).

Fórum de César (c. $12.000 \mathrm{~m}^{2}$ ) forma um retângulo muito alongado, com três lados circundados por um pórtico colunado duplo, transformando sua área central em uma praça porticada fechada, cujo templo, que ocupa praticamente todo o lado menor oposto à entrada, constitui a conclusão e o elemento unificador. Ainda na Gália, César enviou instruções para a sua construção, em 54 a.C., mas o Templo de Vênus Generatrix, na parte oeste da praça, e o Fórum propriamente dito só foram consagrados em 46 a.C., sendo Otaviano quem os terminou após a morte de César. 


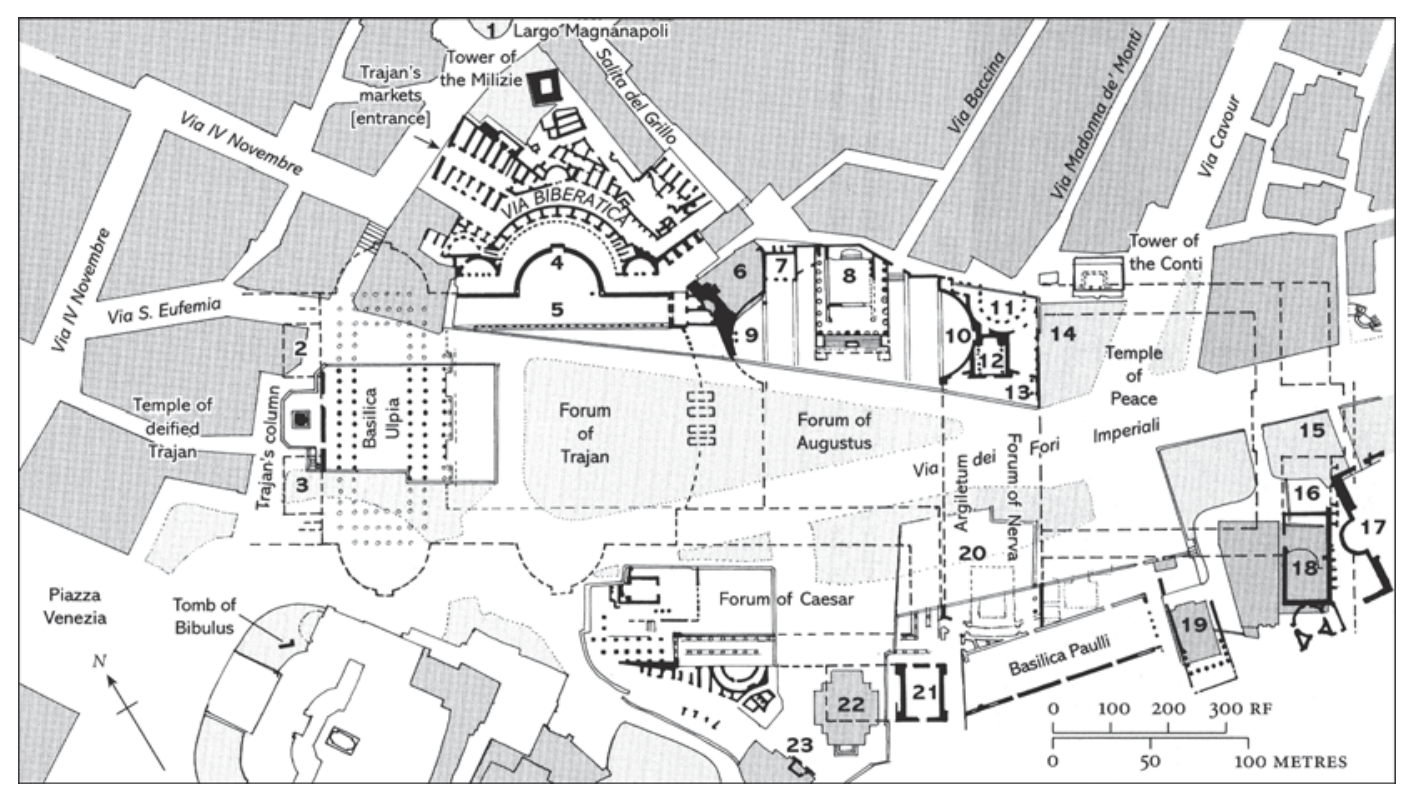

Fig. 1. Planta dos Fóruns Imperiais. 1. Porta republicana da cidade; 2 e 3. Bibliotecas de Trajano; 4. Êxedra do Fórum de Trajano; 5. Pórtico do Fórum de Trajano; 6. Casa dos Cavaleiros de São Jorge; 7. Sala da estátua colossal; 8. Templo de Mars Vltor; 9 e 10. Êxedras do Fórum de Augusto; 11. Porticus Absidata; 12. Templo de Minerva; 13. "Le Colonnacce"; 14 e 15. Templo da Paz; 16. Sala da Planta Marmórea (de Roma); 17. Basílica de Maxêncio; 18. Igreja de S. Cosmo e S. Damião; 19. Templo de Antonino e Faustina; 20. Escavações recentes (1996 em diante); 21. Cúria Júlia; 22. Igreja de S. Lucas e Sa. Martina; 23. Cárcere Tuliano (Claridge 1998: 146).

O projeto de César não era uma simples extensão do Fórum Romano, mas um espaço demarcado distinto, associado aos negócios públicos e ao engrandecimento de seu patrono. "Como o nome implica, o novo Fórum Júlio tornou-se, de fato, um heroon a César” (Favro 1996: 62), com evidente função ideológica e características propagandísticas. Para Coarelli (2003: 128-9) e Balty (1991: 288 ss.), provavelmente baseava-se no modelo dos santuários helenísticos dedicados aos soberanos divinizados: os Kaisareia de Alexandria e de Antioquia.

Para Zanker (1992: 45), o Fórum de César - assim como o teatro de Pompeu, no Campo de Marte - era um edifício público de caráter "privado" que alcançou uma nova dimensão. "A magnitude e as pretensões destes monumentos correspondiam à importância destas duas personalidades nos tempos da res publica decadente".

O Fórum de Augusto foi inaugurado em 2 a.C. (Fig. 2). Oficialmente, a função da nova praça monumental era desafogar a multidão que se aglomerava nos dois fóruns mais antigos e propiciar novos espaços para os processos e as transações comerciais. Mas ele foi, antes de tudo, "um centro de prestígio, destinado a glorificar o imperador, especialmente do ponto de vista das suas funções militares e 'triunfais'” (Coarelli 2003: 130).

No grandioso muro de cerca de $33 \mathrm{~m}$ de altura (que protegia e isolava o fórum da vizinha Subura) havia duas entradas e um forte desnível com relação ao antigo bairro popular (o vale entre o Quirinal e o Esquilino).

fórum ocupava aproximadamente $14.700 \mathrm{~m}^{2}$ e a praça possuía duas grandes êxedras perfeitamente simétricas que ficavam encaixadas no fundo dos pórticos laterais. Estas êxedras são uma inovação que também aparecerá no Fórum de Trajano. Nelas havia estátuas dos heróis, reis e de figuras mitológicas da história de Roma, da Liga Latina, do Império e da família Júlia. $\mathrm{O}$ Fórum de Augusto como um todo combina associações estatais (as esculturas das figuras da história da própria Roma), da família Júlia (os 


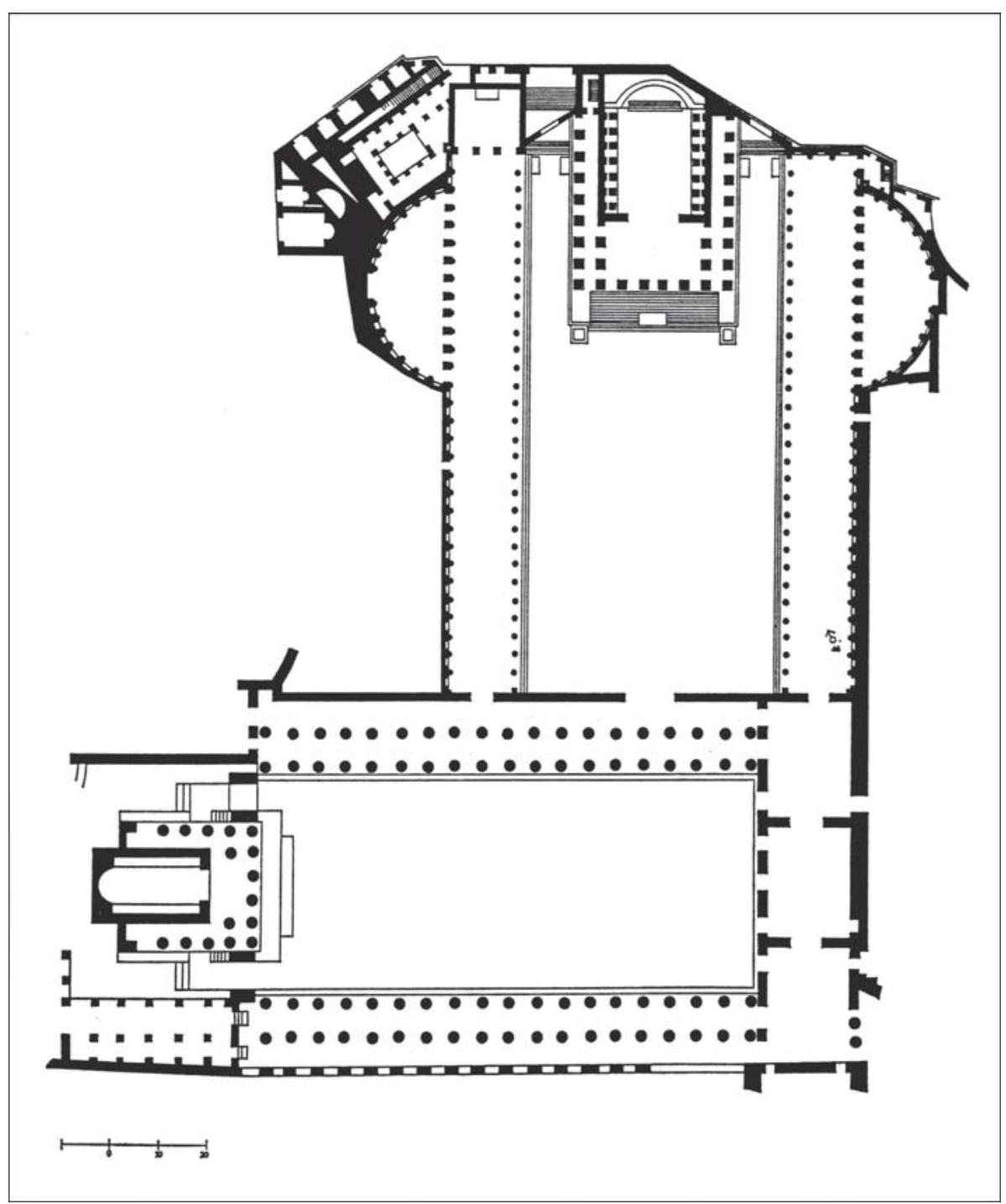

Fig. 2. O Fórum de Augusto e a junção (hipotética) com o de César (Gros 2002: 216, fig. 255).

retratos dos membros da gens Iulia), da última conquista do reino grego (as esculturas gregas) e particulares de Augusto (como o deus Mars Vltor, Marte Vingador).

As descrições iconográficas e sua análise, atualmente, seguem, com poucas alterações, a apresentada por Paul Zanker (Augusto y el poder de las imágines, 1992) [por exemplo, as de Favro (1996), Coarelli (2003), Mierse e Wagg (1999) e J. Ward-Perkins (1981)] (Fig. 3). No Fórum de César é evidente a afirmação do poder monárquico através da divinização virtual do ditador; aqui, segundo um modelo típico da propaganda augustana, percebe-se um compromisso entre tradição e inovação: recupera-se a história republicana e, ao mesmo tempo, identifica-se esta com a história da própria família Júlia. A propaganda augustana sugere que o Império é a conclusão lógica e providencial da República. Desse modo, o Fórum de Augusto se torna uma espécie de imenso átrio patrício, com os retratos dos antepassados. A estátua de Augusto no carro triunfal, que ocupava o centro do fórum (provavelmente na parte não escavada), estava 


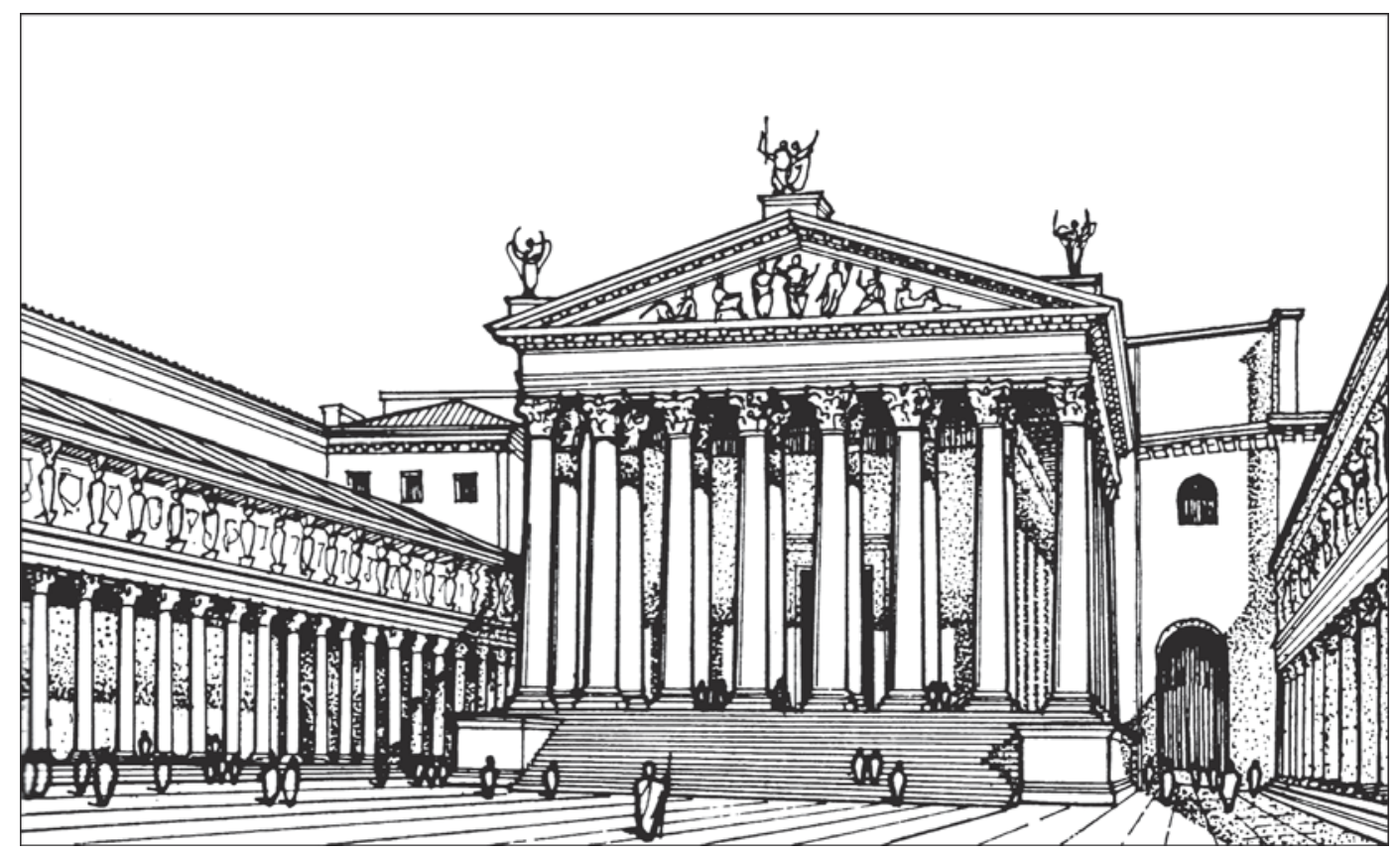

Fig. 3. Reconstrução da fachada do Templo de Mars Vltor e dos pórticos (Favro 1996: 97; fig. 51).

posicionada, enfaticamente, no eixo do templo (Coarelli 2003: 131-2).

O Fórum Transitório, ou de Nerva (Fig. 4), foi inaugurado em 97 d.C., após a morte de Domiciano, seu real construtor. O nome de Transitorium se deve à posição da praça, que cobriu o primeiro trecho do Argileto, a rua que ligava o Fórum Republicano à Subura. $\mathrm{O}$ Fórum de Nerva passou a fazer a ligação entre os três fóruns agora existentes e o Templo da Paz, a leste. Por causa do pouco espaço disponível, a praça assume uma forma muito alongada e estreita, com $120 \times 45 \mathrm{~m}^{1}$, o que impediu a construção de um pórtico. Em seu lugar, no lado direito (leste) da praça, foi construída uma grande colunata, que se ligava à fachada original do Templo da Paz. No fundo da praça, no lado norte, estava o Templo de Minerva, divindade venerada por Domiciano, mas a inscrição leva o nome e os títulos de Nerva.

(1) Chaisemartin (2003: 174) confirma estas medidas de Coarelli. Já Claridge (1998: 156), diz que o Fórum de Nerva media 117 x 39 m. Richardson Jr. (1992: 168) não fornece suas dimensões.

\section{O Fórum de Trajano}

Todos esses fóruns apresentam uma planta regular: praça quadrangular cercada por pórticos e um templo em um dos lados menores. Não possuem basílica, mas as funções judiciárias (que passaram a ser exercidas nas basílicas do antigo Fórum Romano) eram exercidas comprovadamente pelo menos no Fórum de Augusto, especificamente nas êxedras (Carnabuci 1996). Já o Fórum de Trajano apresenta, por sua vez, uma grande inovação em Roma: a presença de uma basílica fechando um dos lados menores; e uma grande diferença: a ausência de um templo na área cercada pelos pórticos.

Foi o último e o mais grandioso dos Fóruns Imperiais, construído por Trajano entre 107 (ano de seu triunfo sobre os dácios) e 113 d.C. Na falta de espaço para a sua construção, Trajano eliminou a selada (e as suas construções, como o atrium Libertatis) que unia os montes Capitolino e Quirinal. Seu arquiteto foi Apolodoro de Damasco, um competente engenheiro militar que havia feito a ponte sobre o Danúbio que iniciou a campanha da Dácia. 


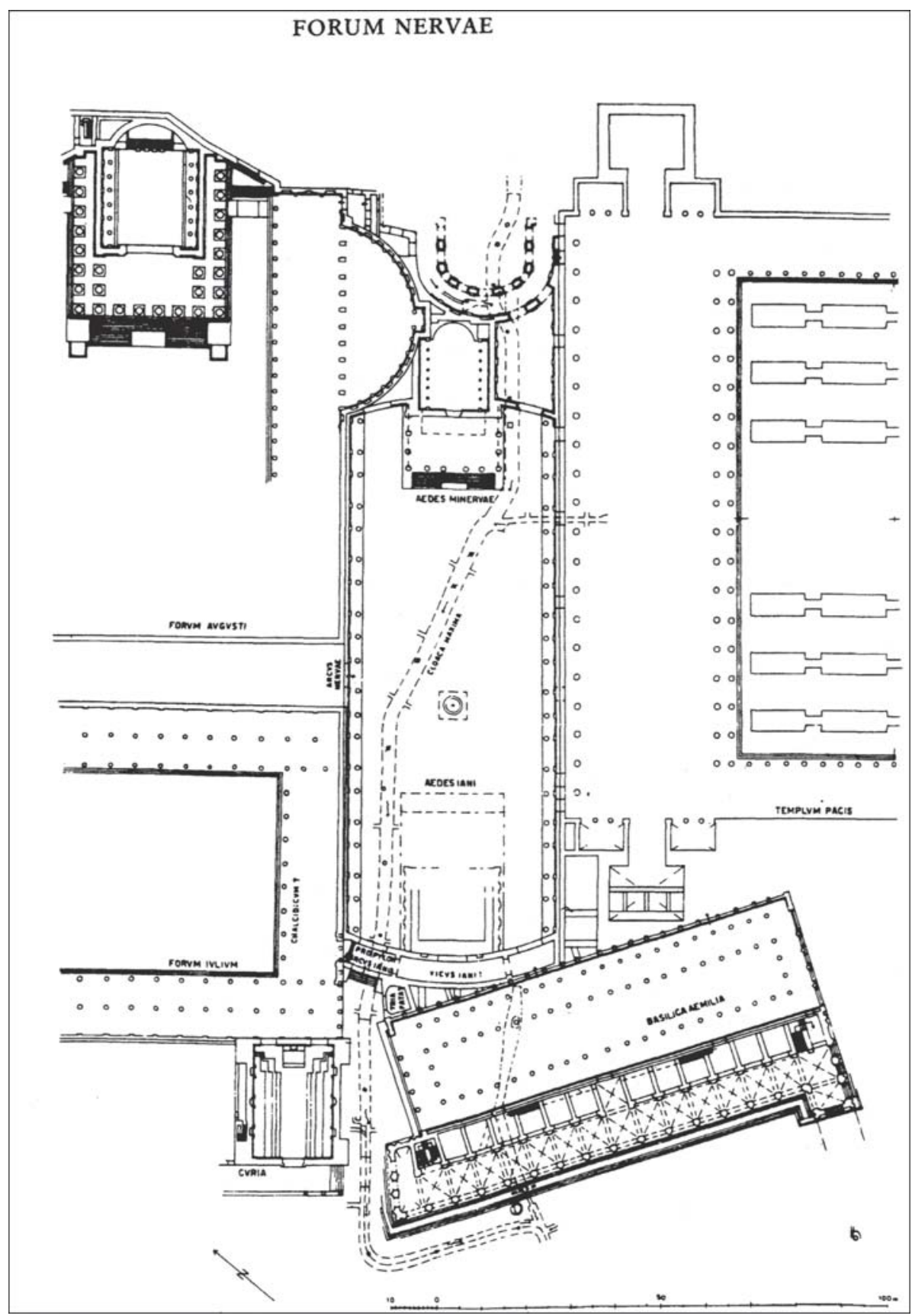

Fig. 4. Fórum de Nerva, Porticus Absidata e Basílica Emília (ou Paula), planta restaurada (Richardson Jr. 1992: 168, fig. 39).

A reconstituição do fórum e da basílica, especialmente no que diz respeito à decoração, é feita através de imagens monetárias. Construído ex manubiis, com os espólios da conquista da Dácia, de 106 d.C., media 300m de comprimen- to por $185 \mathrm{~m}$ de largura. Foi inaugurado em janeiro de 112, mas a Coluna Trajana, ainda inacabada, somente em maio de 113 foi inaugurada, junto com a reconstrução do Fórum de César (Fig. 5). 


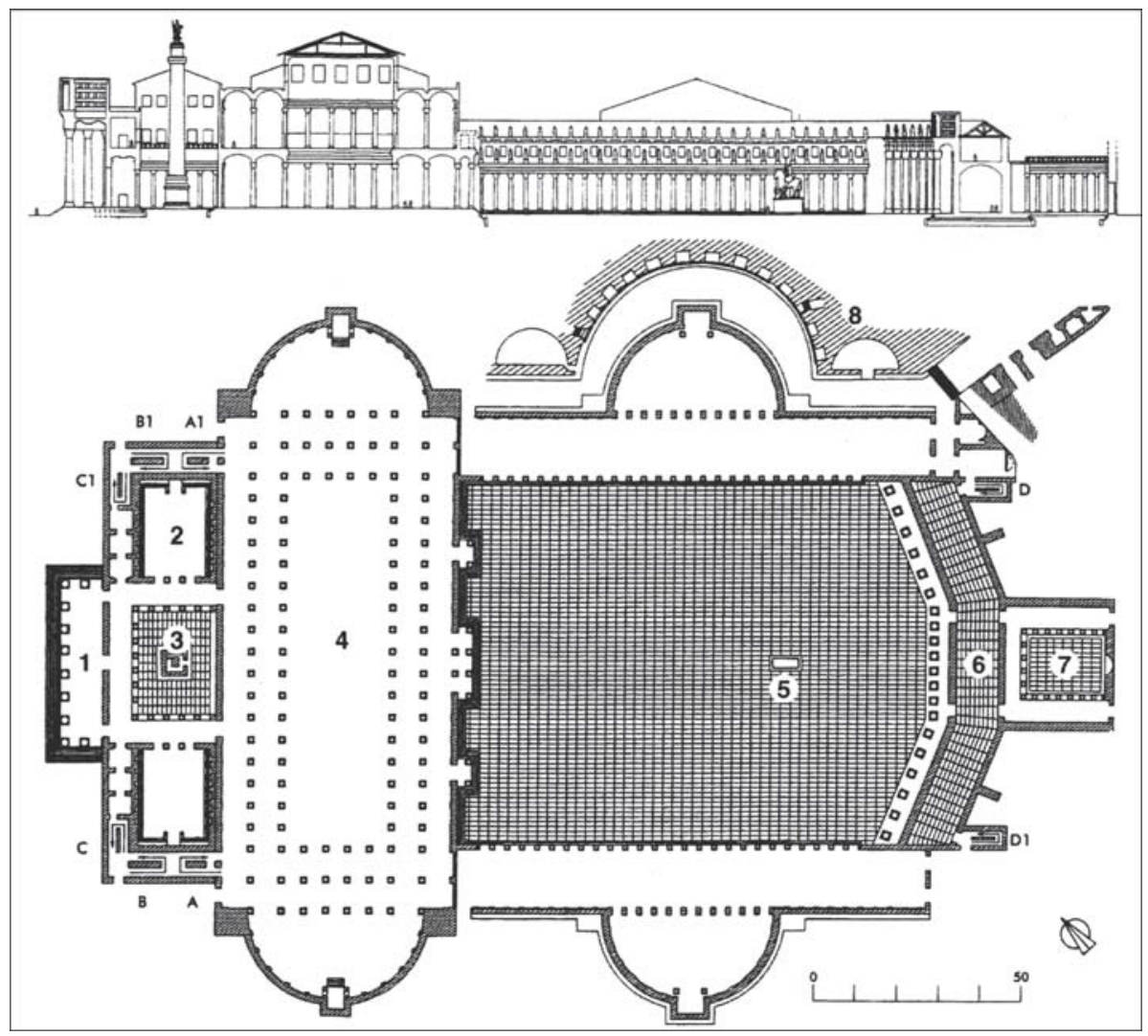

Fig. 5. O Fórum de Trajano, planta baixa e corte. 1. propileu; 2. bibliotecas; 3. Coluna Trajana; 4. Basílica Ulpia; 5. estátua eqüestre de Trajano; 6. galeria tripartida; 7. aula; 8. Mercados de Trajano. A, B, C e A1, B1, C1: caixas das escadas (Chaisemartin 2003: 198). Chaisemartin utiliza os esquemas de Meneghini (2001: 245-268), que excedem a altura da Basílica Ulpia.

O monumento se articulava sobre terraços ligeiramente elevados um com respeito ao outro, de sul a norte. A entrada ficava no lado sul do Fórum de Augusto, através de um grande arco com vão único; a grande praça retangular, pavimentada com blocos de mármore italiano, possuía no centro a grandiosa estátua eqüestre de Trajano.

Os dois lados da praça eram fechados por pórticos colunados, dois degraus ${ }^{2}$ acima da praça. Os pórticos mediam $112 \mathrm{~m}$ de comprimento (380 pés romanos) por $14,8 \mathrm{~m}$ de largura (50 pés romanos), pavimentados com mármore pavonazzetto, vermelho e amarelo, original da Frígia. Na sua parte posterior, havia duas

(2) Três degraus, segundo Claridge (1998: 162). grandiosas êxedras semicirculares, muito provavelmente inspiradas nas do Fórum de Augusto. No interior, as êxedras tinham dois andares e nichos com estátuas. A galeria colunada era utilizada para expor os retratos dos imperadores precedentes e dos membros mais importantes da família imperial. O fundo da praça era fechado pela imponente Basílica Ulpia.

Trajano seguiu o esquema do fórum fechado, mas colocou uma basílica integrada aos pórticos. Apesar de as basílicas do Fórum Romano servirem como delimitadoras do próprio Fórum, elas eram edifícios independentes de uma praça que permitia uma grande circulação, inclusive de carros, e não uma praça fechada, com acesso restrito e que criava um ambiente isolado do resto da cidade. Fóruns, como o de César, Augusto e Trajano, formam 
uma fronteira entre o centro majestoso e o resto da cidade.

A Basílica Ulpia, até o final da Antigüidade, era considerada o edifício mais imponente de Roma. Seu tamanho era gigantesco - 8.500 $\mathrm{m}^{2}$ de área coberta, perto de $171 \mathrm{~m}$ de comprimento com as absides e $59 \mathrm{~m}$ de largura sem as sacadas -, sua construção luxuosa e sua posição serviam como cenário para o Fórum de Trajano. Como nas basílicas do velho Fórum, um espaço central retangular era circundado por duas naves formando um duplo deambulatório; nenhuma parede dividia este volume interno, ritmado apenas pelas colunas que definiam as "naves" central e laterais e separam as êxedras do quadrilátero central (Gros 2002: 253).

Infelizmente, sua reconstituição completa é impossível (as escavações antigas e incompletas e as anastiloses parciais mais ou menos arbitrárias embaralharam irremediavelmente a imagem), o que deixa apenas sua planta e sua (mais provável) elevação. A interpretação por meio de imagens monetárias é sumária e apenas da parte central do edifício, voltada para o fórum, além de vários fragmentos da Forma Vrbis terem se perdido (há apenas desenhos mais ou menos exatos de um códex do Vaticano para as êxedras laterais). Os estudos, no máximo, propõem hipóteses plausíveis que podem servir de base para uma análise das estruturas (como o estudo de C. M. Amici 1982).

Para Gros, os únicos elementos originais da Basílica Ulpia são as imensas êxedras, uma vez que sua planta reproduz os esquemas anteriores. "Em primeira análise, elas aparecem como acréscimos um tanto supérfluos, não integrados ao conjunto arquitetônico, mesmo se seu isolamento espacial seja atenuado pelos eixos visuais propiciados pelas clarabóias entre as colunas que orlam a corda. Mas não nos enganemos: a importância delas no funcionamento do edifício é primordial; além de abrirem-se como êxedras que oferecem ao mesmo tempo áreas de descanso e perspectivas em direção à nave central, elas orientam também o espaço desta em direção às suas duas extremidades ao mesmo tempo, pois em cada um de seus vértices se eleva um tribunal. Estes deviam destacar o eixo longitudinal de toda a construção, pois os capitéis que pertencem verossimilmente à fachada dístila de suas entradas, com 1,30 m de altura, sugerem uma ordem mais elevada que a que ritmava os muros curtos das êxedras" (Gros 2002: 253).

Reexaminando os vestígios e as imagens monetárias trajanas, Packer e Sarring (1992: 72ss., apud Gros 2002: 254) concluíram que a nave central possuía apenas dois níveis, uma ordem coríntia na parte inferior e uma jônica na superior, com os entablamentos respectivos, somando ao todo $25 \mathrm{~m}$ do piso ao teto. Com o telhado, externamente o conjunto se elevava a 100 pés, ou 29,38 m (Gros 2002: 254).

As reconstruções apresentadas por Peter Connolly e Hazel Dodge (1998: 231-35, especialmente nas páginas 234-5) baseiam-se no estudo de James Packer (1997).

Para Paul Zanker (1970, apud Virlouvet 1985), no Fórum de Trajano a composição não era focada, como nos de César e de Augusto, no templo: "o monumento em torno do qual se articulava o espaço era a basílica Ulpia, que fechava a noroeste a praça principal e cuja grandiosa fachada era provavelmente o primeiro elemento a atrair o olhar de quem entrava no fórum através da entrada triunfal" (Virlouvet 1985: 152).

A forma como os fóruns romanos, a partir do de César, se diferenciaram do antigo Fórum Republicano, se assemelhando a uma estrutura urbana que Roma não possuía - ou seja, o modelo regular de ruas e quarteirões - parece demonstrar a introdução, quase forçada, de uma forma urbana regular dentro do centro da capital. O Fórum de Trajano é o exemplo mais "invasor" da malha urbana romana: o imperador introduziu à força sua grande praça, indo de encontro, inclusive, aos costumes religiosos. Não há registro, nos fóruns imperiais, da presença de outros tipos de santuários que não o único templo em posição axial, como acontecia no Fórum Romano. Já no de Trajano, foi feito um heroon a Trajano e o templo ao imperador divinizado ficava externo aos pórticos que o delimitavam (onde, exatamente, ainda permanece uma incógnita). 


\section{O Templo do Divino Trajano}

Neste ponto, convém abrir um parêntese para falar sobre o templo dedicado ao Divino Trajano. A existência do templo nunca foi colocada em dúvida. Porém, no local mais lógico para sua localização, a norte da Basílica Ulpia, alinhado com o eixo principal do fórum, foi demonstrada, após recentes estudos arqueológicos, a impossibilidade de sua existência (ver especialmente: Meneghini 1996; Gros 2002 e 2000; Torelli e Gros 2007).

O foco do recente artigo de Amanda Claridge, "Hadrian's lost Temple of Trajan" (2007), é exatamente sobre uma possível localização para o templo do Divino Trajano que, nas suas próprias palavras, "nos últimos dez anos passou de um de nossos mais sólidos constructos [da topografia da Roma antiga] para um dos mais precários” (p. 55). Sua localização - mas não a certeza de sua existência - ainda é desconhecida, embora "sua posição e estilo arquitetônico, sua relação com a Coluna [de Trajano] e o restante do Fórum tenham sido analisados e reconstruídos no papel com riqueza de detalhes" (ibidem).

No final do século XX, predominava a teoria de que o Templo ficaria exatamente em frente à Coluna, no eixo do fórum, no lado norte (Fig. 6). Tal "certeza” foi derrubada pelo arqueólogo R. Meneghini (então a serviço do Comune di Roma), na década de 1990, após um minucioso trabalho arqueológico (de campo e de pesquisa em arquivos municipais), quando demonstrou que o templo não poderia estar onde "logicamente deveria estar". Novas propostas para sua localização foram feitas e testadas (a

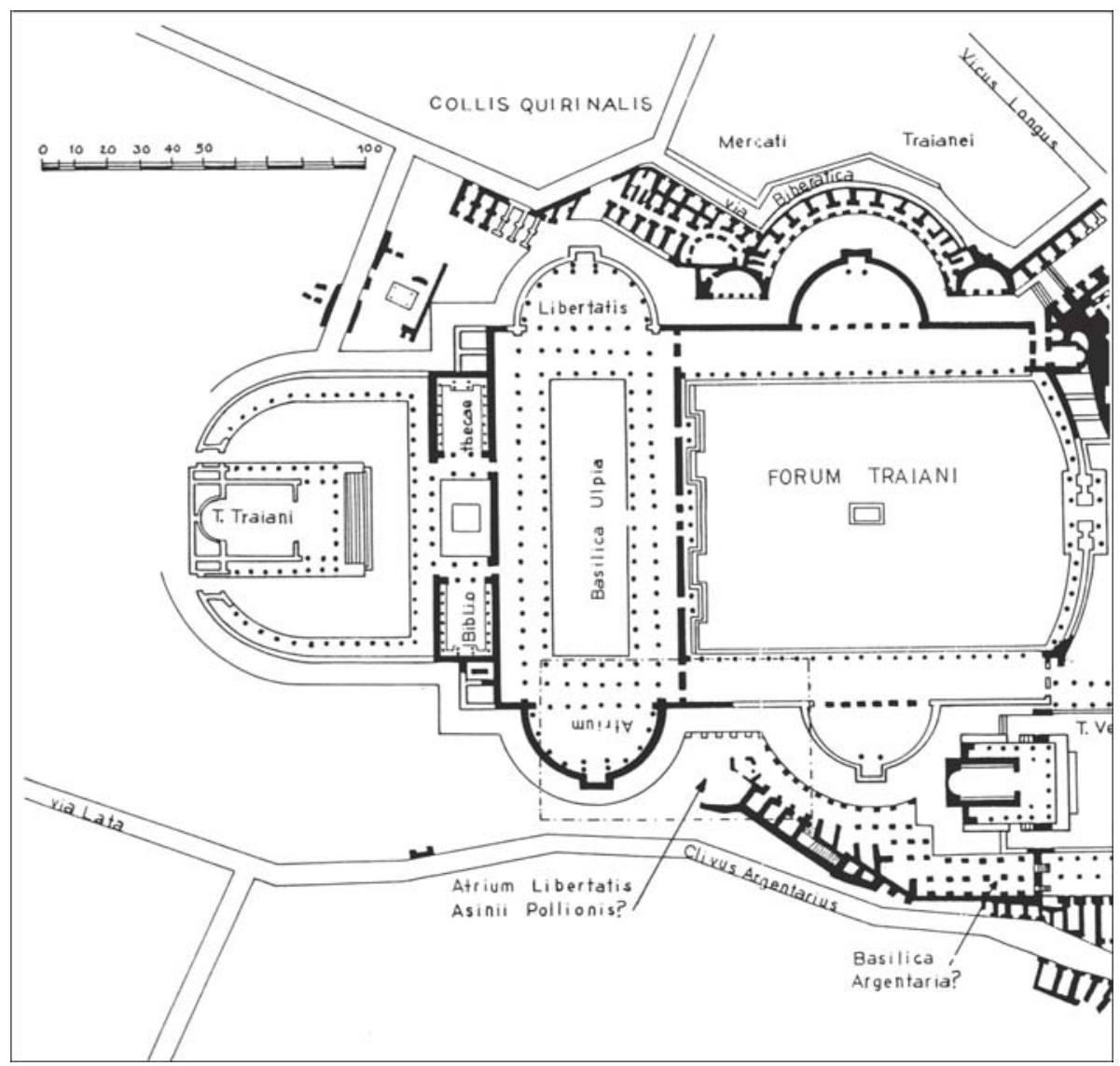

Fig. 6. Reconstituição do Fórum de Trajano com o suposto templo de Trajano divinizado (Gros 2002: 219; fig. 260). 
principal, no lado sul do fórum), com resultado negativo. Por fim, E. La Rocca (superintendente do Comune di Roma) sugeriu que todo o complexo forense deveria ser entendido como um "templum" (La Rocca 2004, esp. 232 f., apud Claridge 2007).

A comprovação da impossibilidade da localização do templo no lado sul do fórum reforça novamente a possibilidade de estar no lado norte, menos escavado por causa da existência de importantes edifícios renascentistas. Para Claridge, porém, o problema da sua localização precisa deixar de ser "um exercício essencialmente hipotético realizado no papel”, que invariavelmente o coloca alinhado com a Coluna de Trajano (a disposição considerada mais óbvia), para começar a levar em conta a existência de inúmeros outros edifícios vizinhos ao fórum, tanto no passado quanto em época moderna. A autora propõe, então, uma nova possibilidade. Devemos ver a suposta presença de axialidade como um engano e, portanto, "o grandioso templo não foi construído perpendicularmente ao fórum". Se tal é verdade, o templo foi englobado, de algum modo, por uma construção vizinha mais recente; mais exatamente, o complexo em eixo inclinado com relação ao fórum do Palazzo Valentini, a noroeste, "onde a tradição oral sempre o colocou” (p. 58).

Mais especificamente, o pátio central do palazzo teria sido construído utilizando o pódio do templo. Claridge expõe as provas para tal proposta. As principais são: a elevação do pátio com relação às ruas do entorno ( $2 \mathrm{~m}$ mais alto); suas dimensões ( 21 X $34 \mathrm{~m}$, desproporcionais ao palácio em si, mas condizentes com as proporções clássicas para a cella de um templo); o estudo de plantas e mapas do século XVI, tanto do projeto do palazzo quanto da própria cidade de Roma. E a consideração final de Claridge aborda a história da construção do complexo forense. Quando Trajano morre subitamente em 117, vários de seus projetos arquitetônicos estavam ainda nas fases iniciais. Caberia a seu sucessor, Adriano, concluir tais projetos; porém, o resultado foram projetos muito diferentes dos de Trajano. Com a divinização deste pelo Senado, Adriano modifica o projeto original para a área norte do fórum, transformando-a em um complexo religioso, o mausoléu sob a Coluna transforma-se em um heroon, constrói o templo a noroeste da Coluna e um palanque (rostra) é colocado entre os dois. "O design do templo segue a tradição romana com relação aos templos para imperadores divinizados" (p. 94), porém Adriano não o dedica ao Divino Trajano (já havia o heroon), mas a si mesmo, inaugurando-o em 126-7, na data que coincidia com a comemoração das suas decennalia. Foi um fato inédito em Roma, a consagração de um templo a um imperador vivo, conclui Claridge.

\section{Os fóruns provinciais}

Os fóruns, os centros administrativos romanos que eram estabelecidos nas províncias junto com a nova malha urbana, refletiam o status da cidade e o prestígio de seus habitantes. Mas parece ter havido uma diferenciação nas províncias ocidentais quando se analisa o conjunto arquitetônico do fórum: embora o esquema mais comum fosse o do fórum retangular, como os Fóruns Imperiais, nestes a basílica, como estrutura separada e independente, desaparece e só "ressurge" com Trajano; nas províncias, porém, a basílica era um elemento indispensável do fórum, mesmo que integrado a ele. Isto acontece porque o "modelo" das cidades coloniais não era exatamente um modelo físico de Roma, uma vez que não era uma cidade planejada, mas fundamentalmente o modelo institucional, reproduzindo as estruturas políticoadministrativas romanas. E sua influência direta, como modelo, se dava principalmente com relação aos edifícios individuais. Mas o inverso também é verdadeiro: vários edifícios públicos como teatros, anfiteatros, termas - surgiram inicialmente nas colônias latinas, no século II a.C. e até mesmo antes, para apenas depois serem encontrados em Roma. O Teatro de Pompeu é um caso típico: foi o primeiro edifício permanente para espetáculos construído em Roma, no século I a.C., inclusive indo contra a tradição romana, de teatros transitórios de madeira; mas já existiam teatros permanentes em diversas colônias itálicas (sobre este tema, ver Zanker 2000). 
Cidades do norte da Itália e das províncias do Ocidente eram imediatamente reconhecidas como "romanas" graças ao distinto complexo capitólio-fórum no centro da cidade. Havia, então, uma configuração especificamente romana de cidade, fosse ela percebida ou não pelos contemporâneos. Zanker considera essa configuração capitólio-fórum central como "a própria evidência de que as novas colônias romanas nas províncias possuíam uma aparência dramaticamente diferente da das veneráveis cidades dos habitantes nativos, e que essa diferença conferia às novas fundações um status especial" (Zanker 2000: 35).

Esse complexo capitólio-fórum se desenvolverá em vários tipos particulares e variações individuais, desde a renovação e expansão de fóruns mais antigos à construção das grandes colônias a partir de Augusto. Tanto no Ocidente quanto no Oriente, a praça foi gradualmente isolada da rede de ruas, enquanto certas funções originais do fórum, como mercado e local de jogos públicos, foram transferidas para outras áreas. O resultado foi que o fórum tornou-se progressivamente um local onde o Estado e seus funcionários podiam exibir seu poder e os cidadãos, sua distinção e status social. O espaço aberto remanescente foi gradualmente preenchido com estátuas e outros monumentos honoríficos (ibidem.).

Nas cidades galo-romanas, o modelo de fórum mais comumente encontrado é o que apresenta aspecto unitário e fechado, cercado por pórticos, como já encontrados nas colônias latinas (como Alba Fucens, Fig. 7). Este modelo possui o Capitólio ou o templo ao culto imperial em um dos lados mais estreitos, geralmente em um nível mais elevado, e a basílica no lado oposto, inserida entre os pórticos, delimitando um dos lados desse espaço fechado, ou uma variação deste, com a basílica em posição transitória - ou de diafragma - de ligação entre duas áreas do fórum.

Zanker não é explícito quanto à questão, mas deixa perceber que o esquema de fórum fechado, cercado por pórticos, foi uma criação latina: surgiu nas colônias da Itália e, daí, foi reproduzida - de forma mais magnífica - por César e Augusto. Então, em um segundo momento, novamente Roma se torna o modelo e "exporta" o fórum fechado por pórticos para as províncias transalpinas (2000).

Segundo Gros (2002: 207 ss.), a forma geral, ou a mais comum, "canônica", do fórum romano, a partir especialmente do século I a.C., é a de uma praça retangular fechada, cercada por pórticos, dominada em um de seus lados menores por um templo e limitada, no lado oposto, por uma basílica e outros edifícios, como a cúria, o tribunal e, eventualmente, a sala dos arquivos municipais (tabularium), o tesouro (aerarium) e a prisão (carcer), distribuindo-se na periferia.

O debate sobre a origem desses fóruns fechados iniciou-se com Hans Lehner, arqueólogo inglês, em 1926. Ele considerava que tais fóruns inspiraram-se nos Principia (os quartéisgenerais) dos acampamentos legionários. Tal teoria é, atualmente, rejeitada, pois foi demonstrado que a origem desse tipo de fórum, considerado arquetípico por vários autores, é muito anterior aos Principia. Constatou-se a existência de fóruns fechados em cidades provinciais romanas contemporâneos e mesmo anteriores aos de Roma, como o de Velleia (Veleia, do final do reinado de Augusto), o de Aequum (de época cláudia), de Glanum (de plena época augustana, no último quarto do século I a.C.; Fig. 8) e, especialmente, o de Alba Fucens, do início do século I a.C., o precursor deste tipo, considerado o primeiro fórum a apresentar tal "evolução arquitetônica” (Balty 1991: 360). Para Balty, e também Grenier (1958: 350-2), na verdade é o acampamento militar que imita a cidade. ${ }^{3}$

Desde o início do Alto Império e ao longo dos dois primeiros séculos d.C., são encontrados numerosos exemplos dos fóruns tripartidos ${ }^{4}$ no Ocidente romano, com ordenação axial ou próxima à axialidade, onde a basílica, em um dos lados menores, defronta o templo maior da cidade (capitólio ou edifício de culto imperial).

(3) Uma discussão completa sobre o tema pode ser encontrada em Jean-Ch. Balty (1991: 357 ss.) e também em Pierre Gros (2002: 220-1).

(4) A descrição dos fóruns tripartidos baseia-se principalmente em Gros (2002: 220-229). 


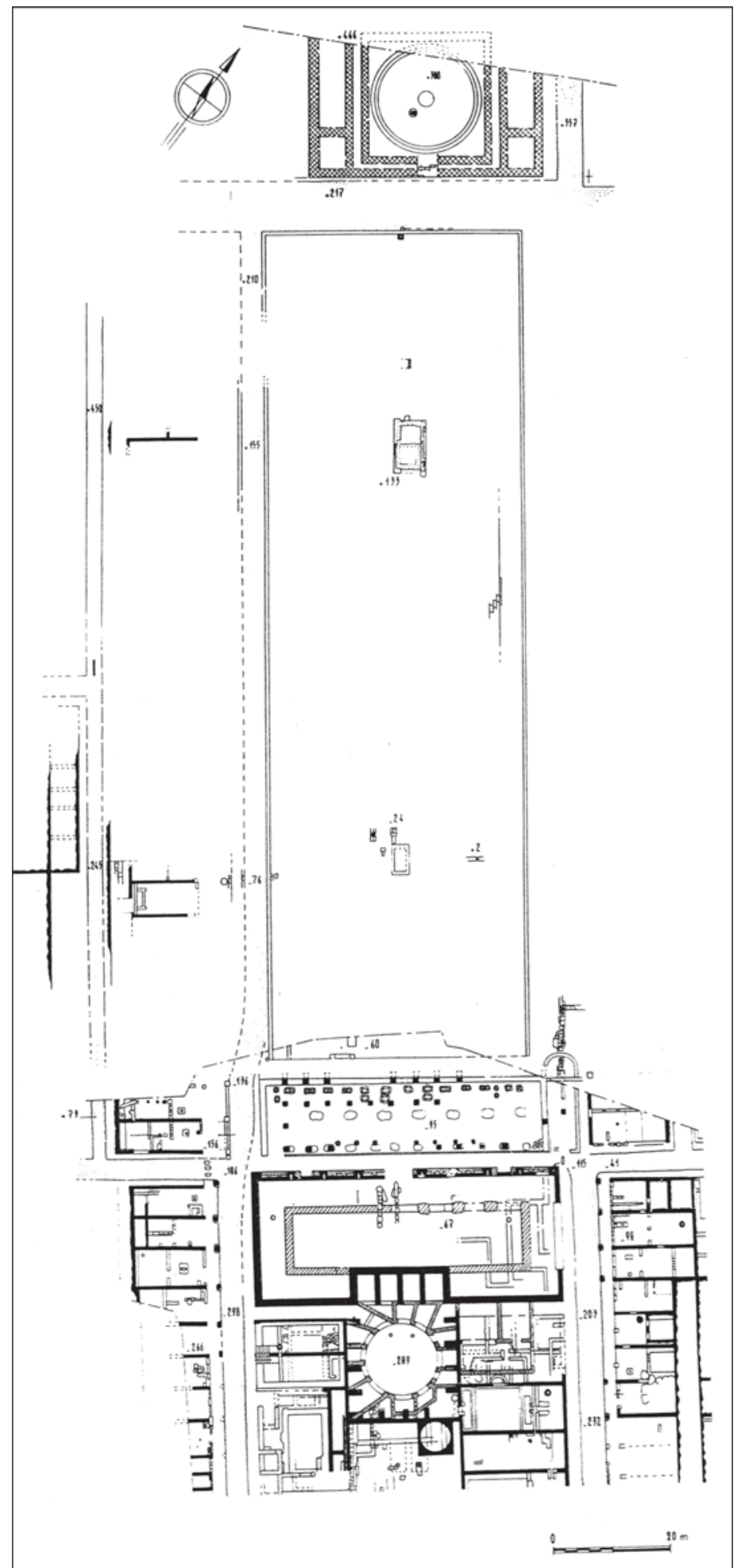

Fig. 7. Fórum de Alba Fucens (Balty 1991; fig. 115). 


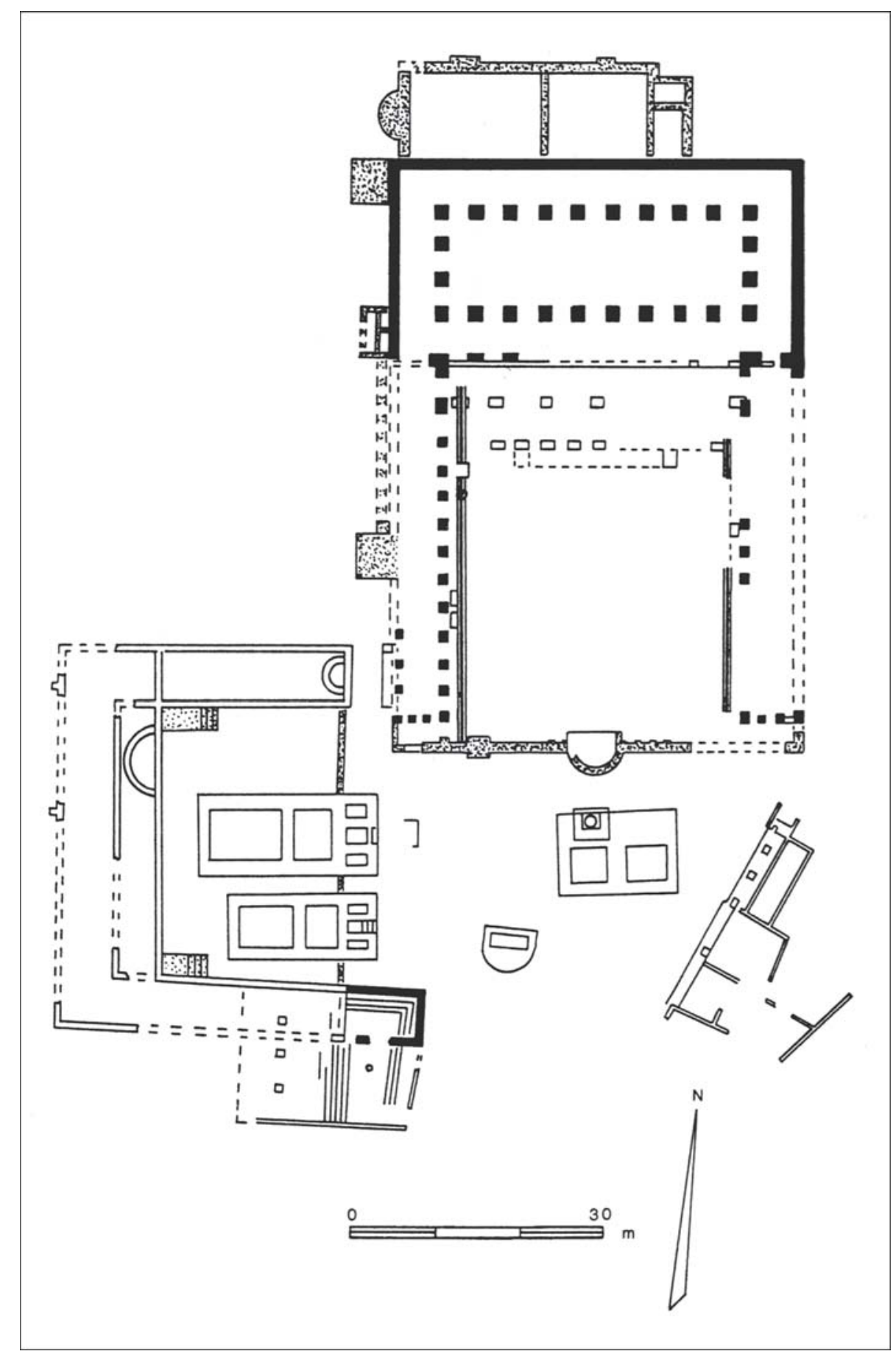

Fig. 8. Planta do fórum de Glanum. Em branco, as estruturas dos anos 20-30 a.C. Em preto, as estruturas augustanas ou tiberianas. Em cinza, as estruturas flávias. A basílica é a estrutura em preto, a norte (Gros 2002: 224, fig. 269). 
São exemplos, para a época augustana e júliocláudia: os fóruns de Segusiavorum (Feurs, Fig. 9), Lugdunum Convenarum (Saint-Bertrand-deComminges), Colonia Iulia Equestris (Nyon, Fig. 9) e Lousonna (Vidy), na Gália Romana; de Baelo Claudia (Belo) e Clunia, na Bética e na Terraconense; de Lepcis Magna e de Cartago, na África. Da época flávia e do início do século II d.C., são os fóruns de Banasa, na Mauritânia; de Thamagadi (Timgad) e de Thubursicu Numidarum (Khamissa), na Numídia; de Lutetia (Paris) e Samarobriva (Amiens), na Gália. E de época antonina, os fóruns de Augusta Rauricorum (Augst), na Gália; de Virunum, na Nórica (Áustria); de Austurica Augusta (Astorga), na Terraconense.

Os fóruns de Augusta Treverorum (Trier, Fig. 10) e de Bagacum (Bavay, Fig. 11), no norte da Bélgica, pertencem a essa mesma série. Nos dois casos, o períbolo em forma de $\Pi$ do setor ocidental parece destinado a abrigar um templo (o que as escavações confirmam, em Bavay). Nos dois casos, na extremidade da grande área, logo depois do espaço de culto, o espaço cercado, no lado oriental, assemelha-se a um santuário de culto imperial no interior do edifício judiciário. Outros exemplos são Périgueux e Arles, na Gália.

Essa forma "canônica", também denominada "fórum tripartido", porém, apresenta diversas variações: a basílica colocada em um dos lados mais compridos (como o de Ruscino, Fig. 12); o templo cercado por um temenos que o isola da praça; os outros edifícios administrativos integrados à basílica; as áreas religiosa e civil separadas por uma via transversal (como em Brescia, Fig. 13); a axialidade do conjunto prejudicada pelas dimensões do terreno ou das

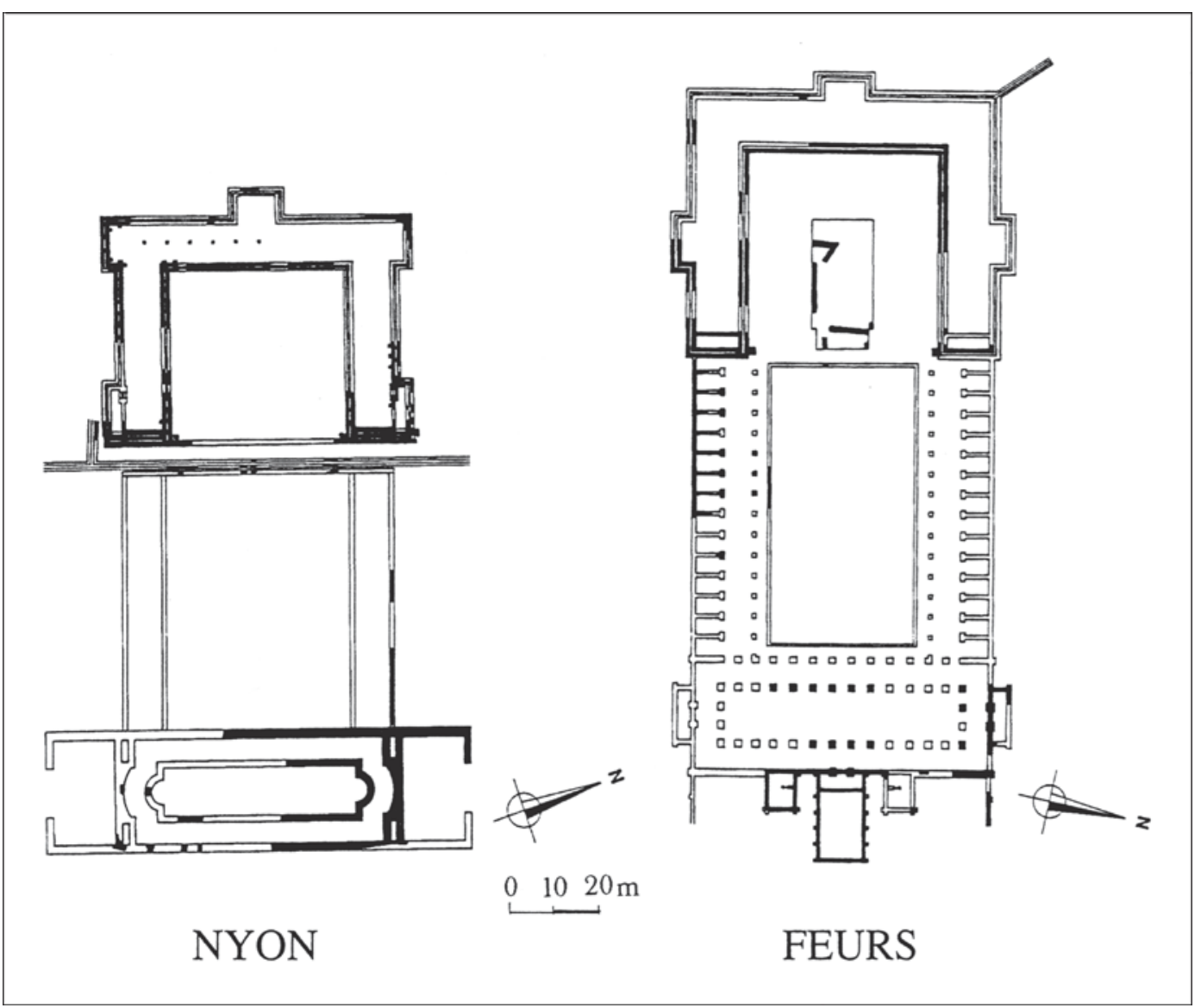

Fig. 9. Plantas dos fóruns de Feurs (primeira metade do século I d.C.) e de Nyon (neroniano) (Gros 2002: 223, fig. 266). 


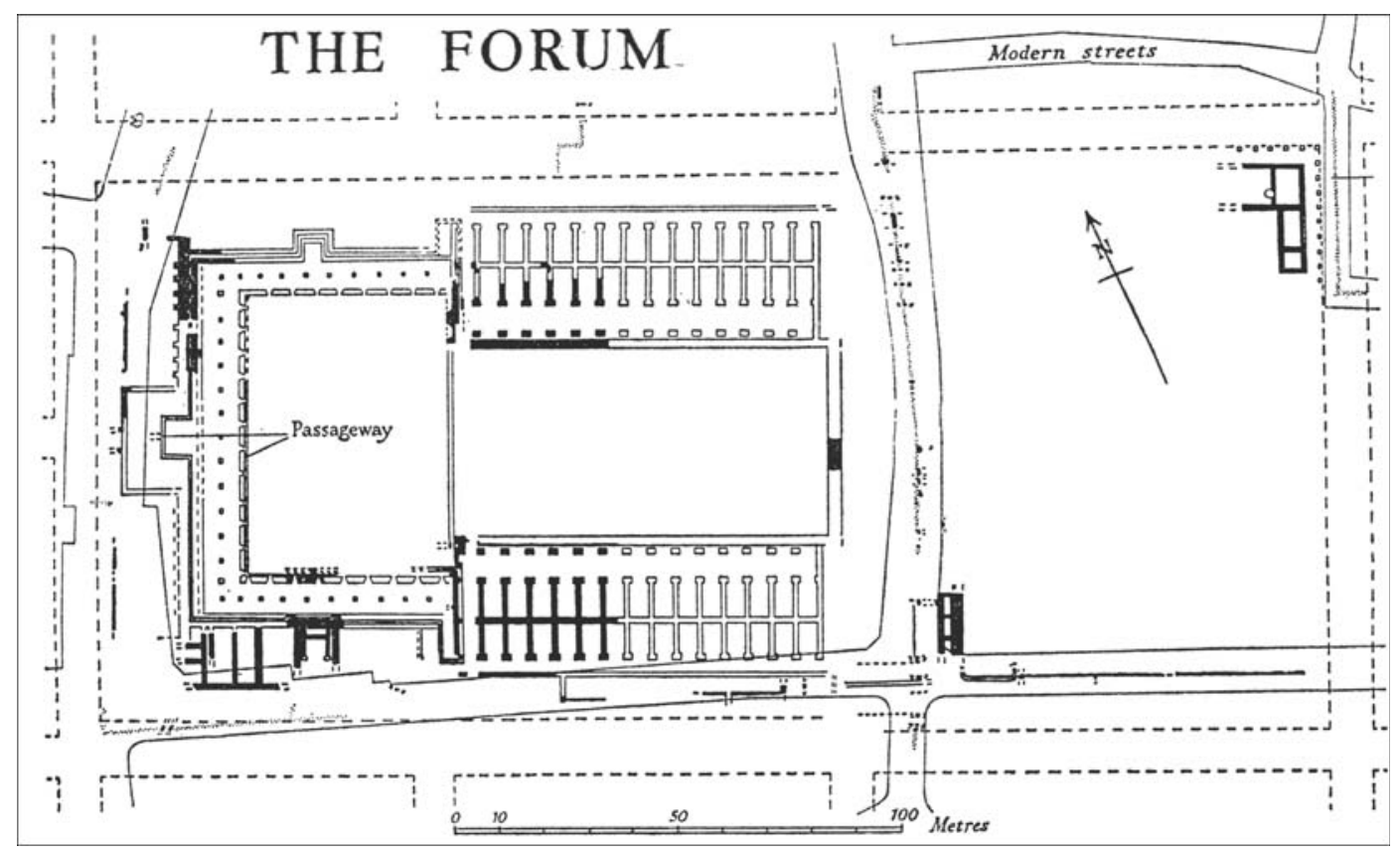

Fig. 10. Planta do fórum de Trier (Augusta Treverorum, Gália Belga), segunda metade do século II d.C. (RaepsaetCharlier \& Raepsaet 1975: 184, fig. 38).

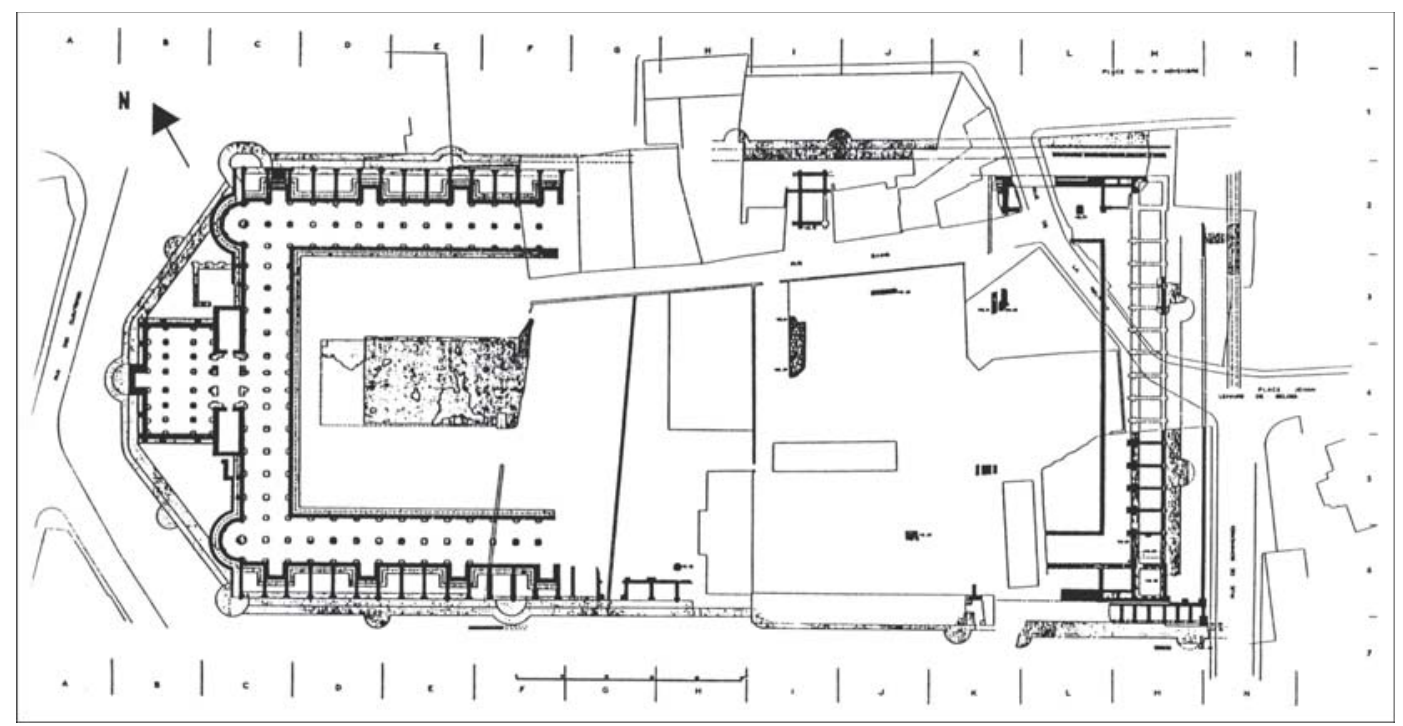

Fig. 11. Planta do fórum de Bavay (século II d.C.) (Gros 2002: 224, fig. 270).

condições do relevo. Numerosas variações podem dar uma primeira impressão de grande diversidade, mas o esquema básico permanece fundamentalmente o mesmo e procede de exigências análogas, mesmo se o equilíbrio e a unidade do conjunto são, às vezes, contrariados.
Em Saint-Bertrand-de-Comminges, por exemplo, o templo fica de costas para a praça, indicando uma justaposição e não uma integração dos edifícios. Glanum, a despeito da exigüidade do espaço disponível, demonstra a adaptação de um programa unitário às características de um 


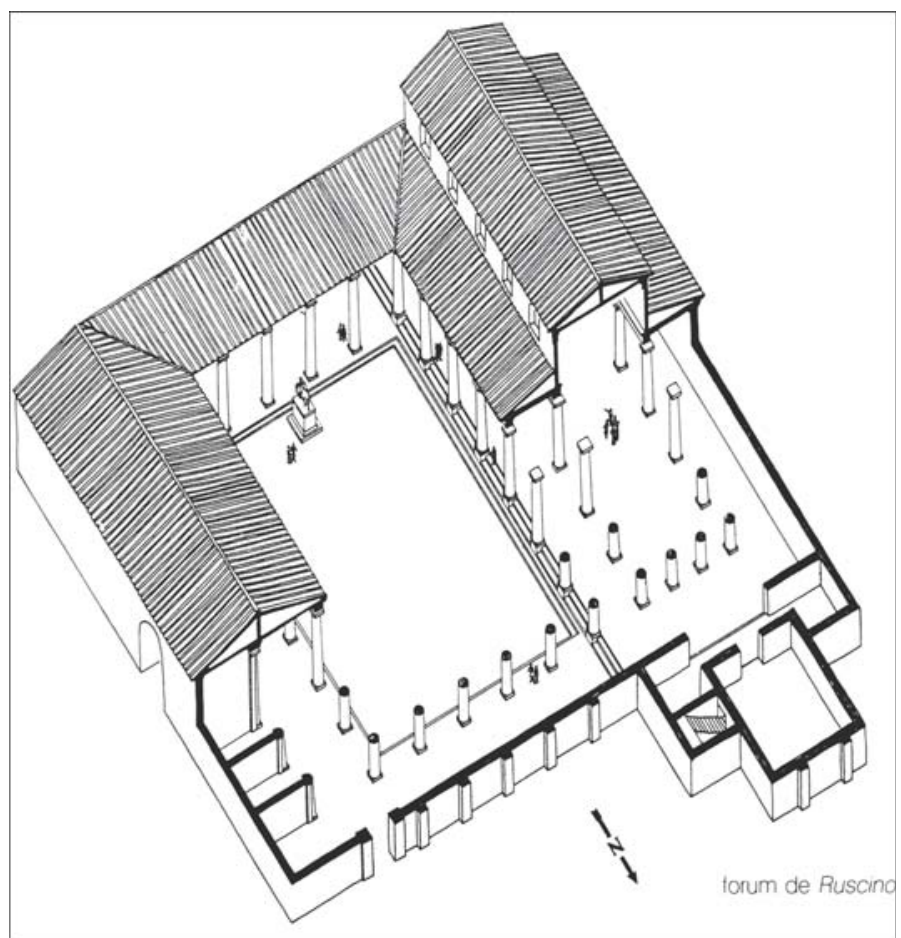

Fig. 12. Reconstituição do fórum galo-romano de Ruscino (Gália Narbonense), entre 20 a.C. e 5 d.C. (Gros 2002: 221; fig. 263).
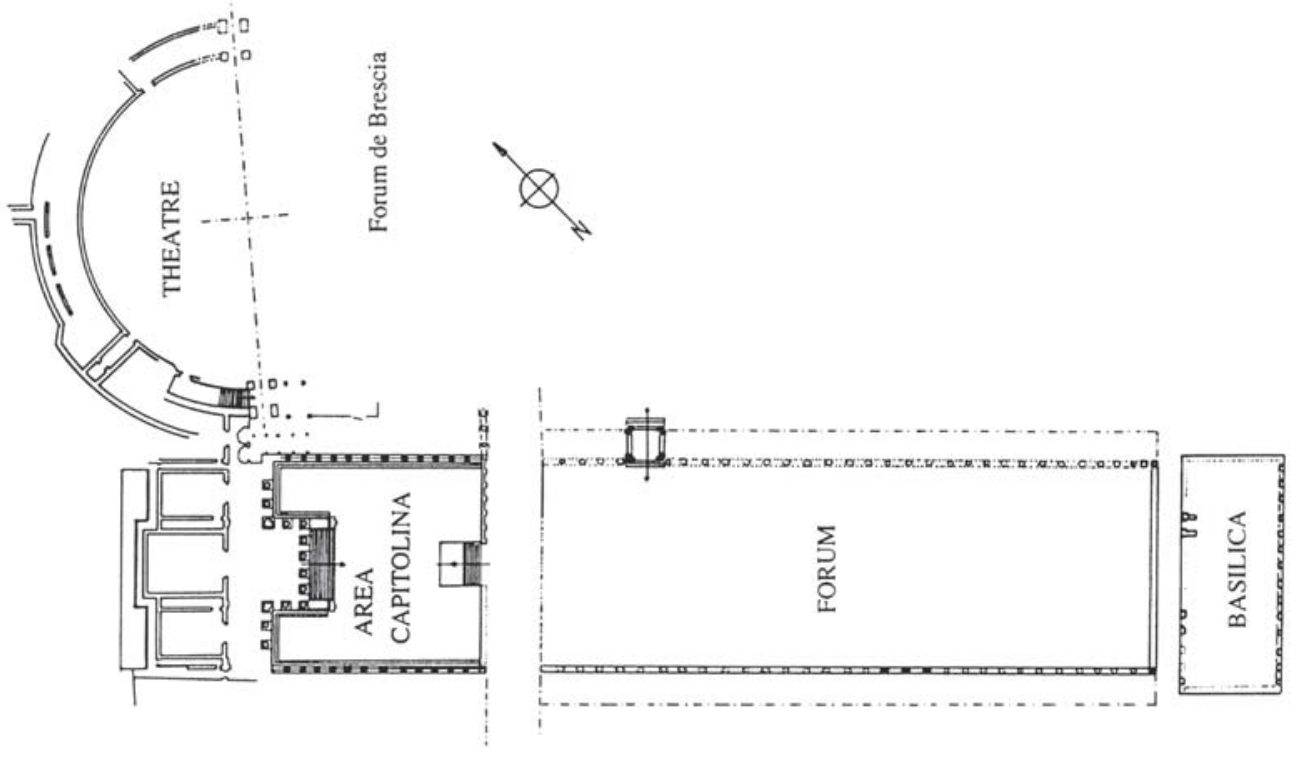

Fig. 13. O fórum de Brescia (Gros 2002: 215, fig. 253). 


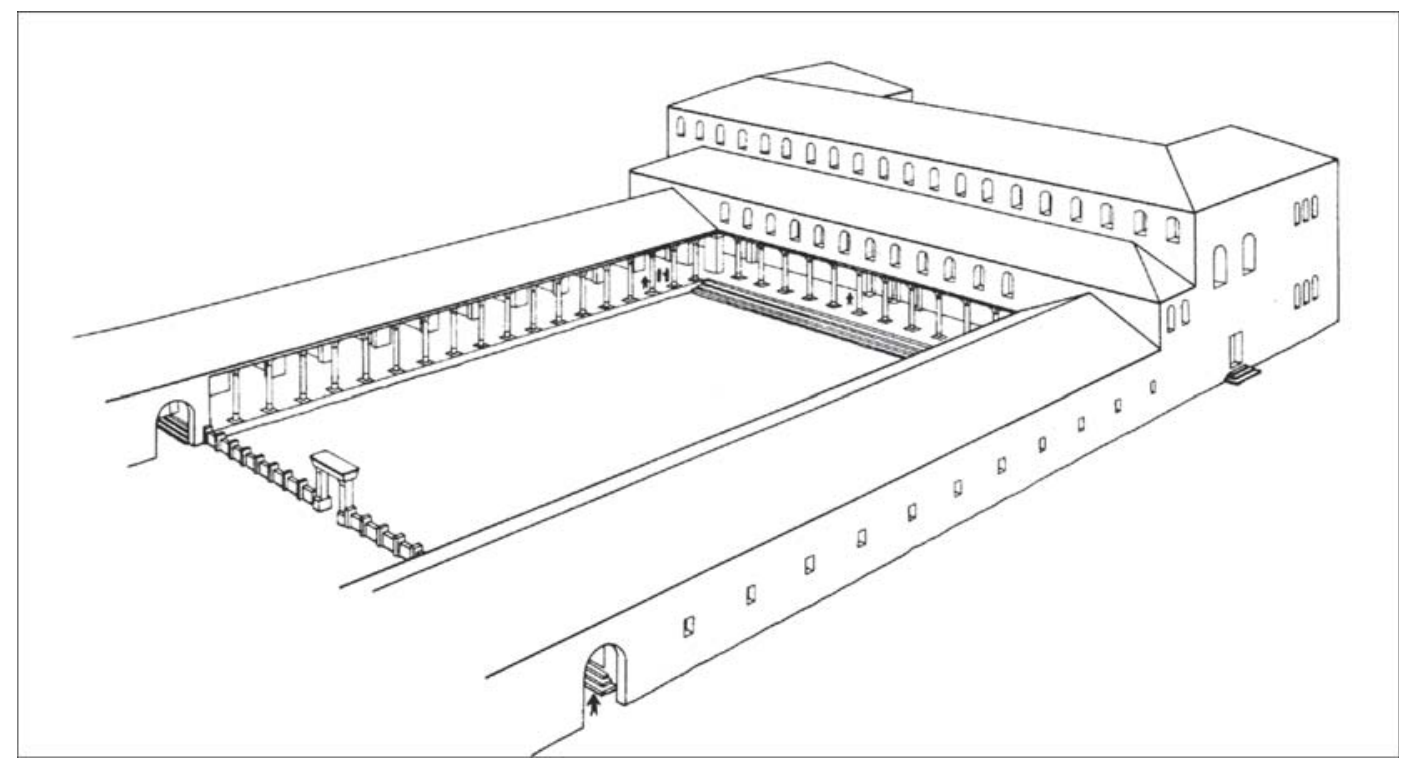

Fig. 14. Reconstrução da segunda fase do complexo fórum-basílica de Martigny (Cavalieri 2002: 239, fig. 53).

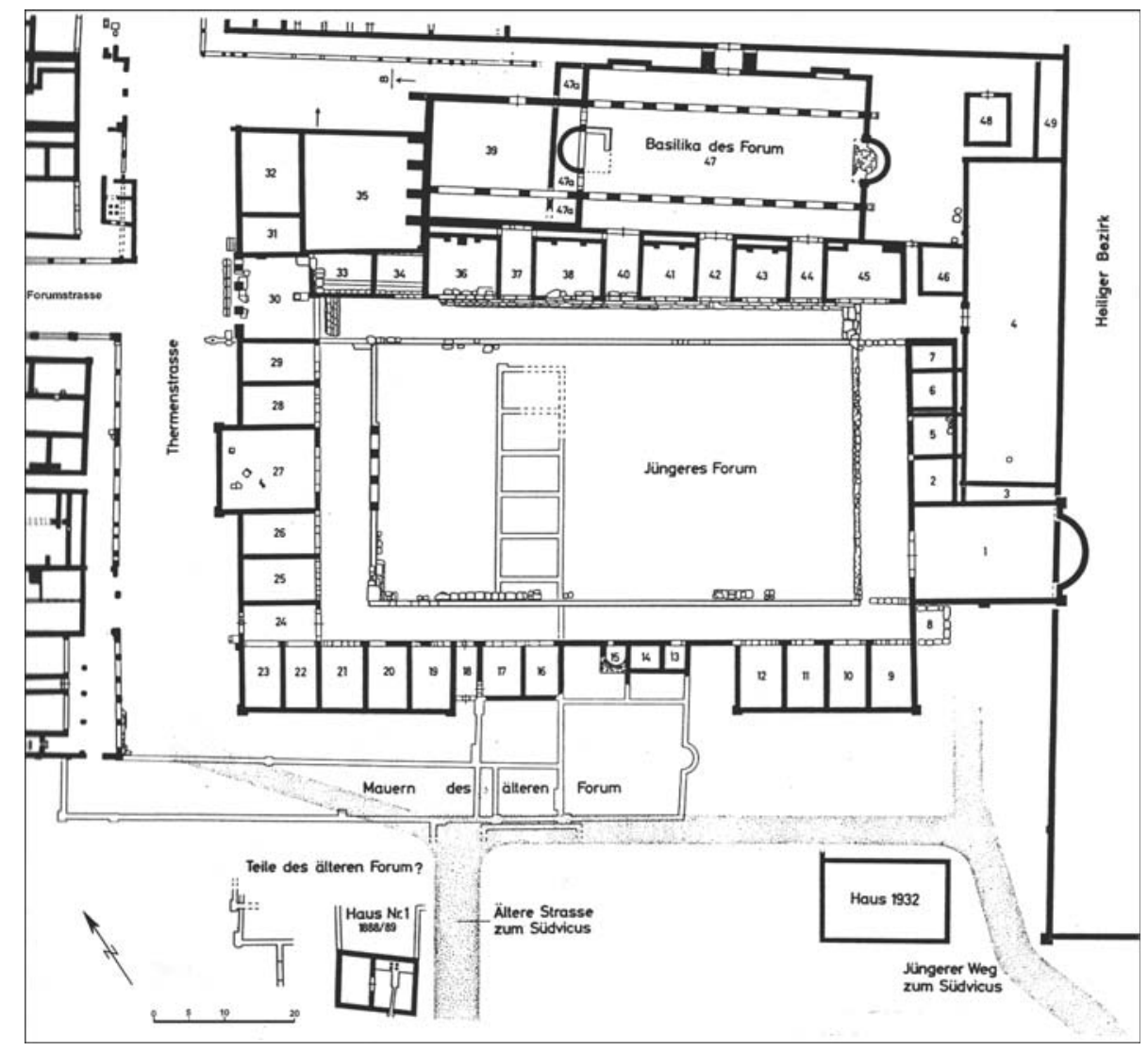

Fig. 15. Cambodunum (Kempten, Alemanha): planta do fórum, segunda fase (Balty 1991: 95; fig. 63). 
terreno difícil e já fortemente modificado por enormes contribuições de aterros: desde o segundo decênio a.C., o conjunto já existia e as ampliações posteriores (particularmente as que dizem respeito à basílica) não modificaram o projeto global (Fig. 8).

\section{Basílicas de tipo ulpiano nas províncias ocidentais}

Houve a reprodução do esquema planimétrico da Basílica Ulpia em diversos contextos, mas é preciso cautela quando encontramos esses modelos nas províncias. Embora, por sua imponência e importância, ela realmente tenha sido copiada alhures, muitas cronologias realizadas recentemente demonstram a existência de basílicas do tipo "ulpiano" anteriores à de Trajano. Então, embora várias basílicas com duas êxedras (ou absides) sejam do século II d.C., nas palavras de Pierre Gros, "as coisas não são tão simples e o dogma da basilica Ulpia como fundadora de uma nova linha deve ser aceito com restrições" (2002: 255).
Há pelo menos três exemplos confirmados de basílicas "ulpianas" anteriores à própria Basílica Ulpia. A basílica do Fórum de Nyon (Colonia Julia Equestris, Fig. 9), por exemplo, na Germânia Superior (antes Gália Belga), após uma datação estratigráfica, demonstrou ser da época de Nero; a de Martigny (Octodurus, Fig. 14) é de época cláudia; e a do primeiro fórum de Kempten (Cambodunum, Fig. 15), na Rétia, dos anos 80 d.C. E os autores não descartam a possibilidade de serem descobertas outras no futuro.

\section{Basílica do Fórum de Augst}

Balty e Gros vêem a basílica de Augst, Suíça (Augusta Raurica, na Germânia Superior, Fig. 16) como "uma das realizações mais significativas do urbanismo romano no Ocidente" (Gros 2002: 258 ss.; Balty 1991: 271 ss.) e exemplo da evolução do plano basilical. Sua primeira versão, de época trajana ou, provavelmente, adriana, segundo Balty, é manifestadamente imitação da Basílica Ulpia. Pouco depois, sofre uma reformulação, as êxedras laterais são suprimidas e retorna-se a um modelo ostensivamente

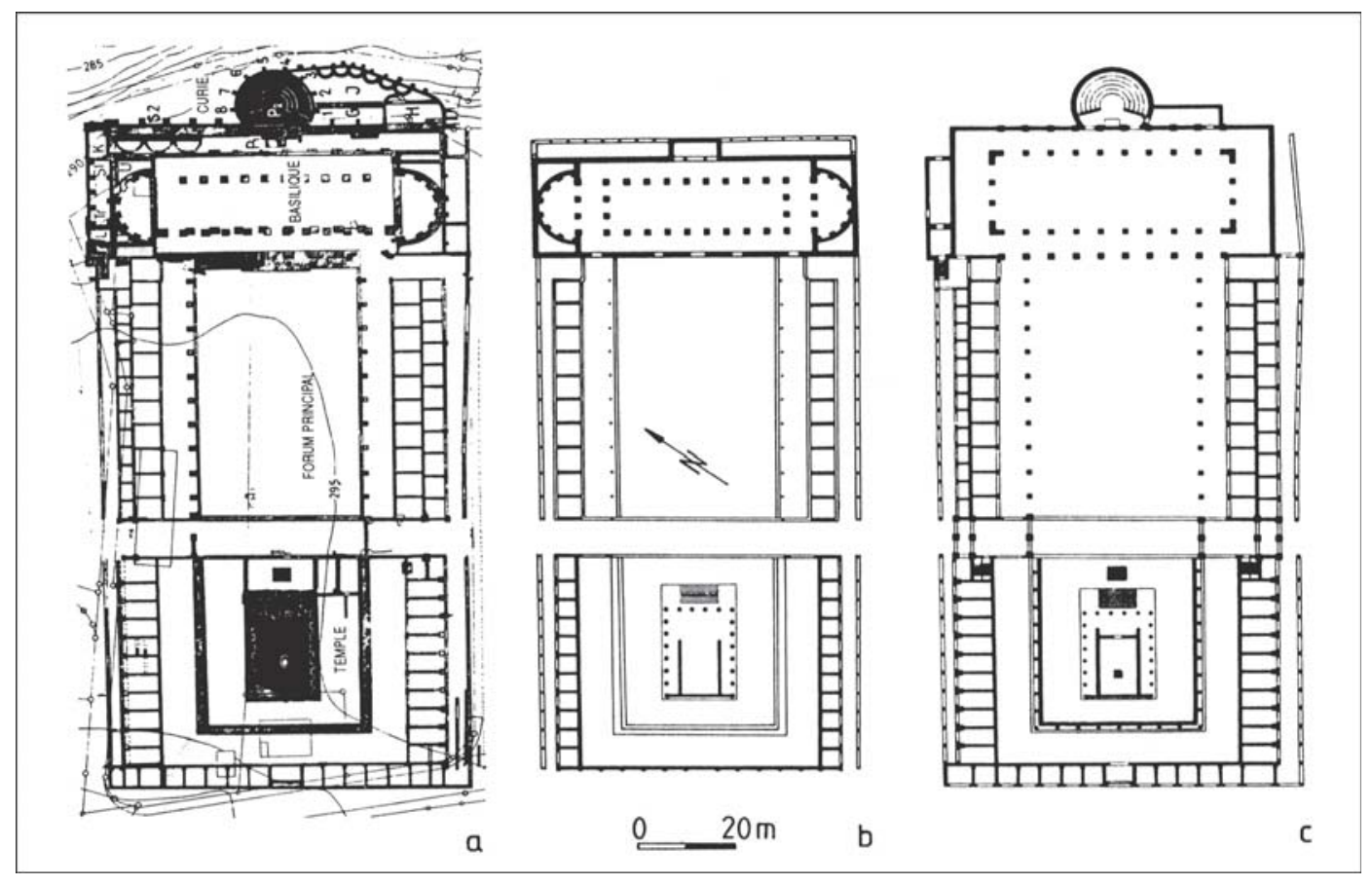

Fig. 16. Planta das três fases sucessivas do complexo fórum-basílica de Augst (Gros 2002: 257, fig. 307). 
anterior, com a diferença do acréscimo da cúria, em forma de torre, no eixo transversal (conjunto datado dos anos em torno de 145 d.C.). A fase seguinte viu especialmente a ampliação vertical do conjunto.

Augst demonstra que não havia, então, uma "evolução linear", um "progresso formal" dos fóruns (e das basílicas) romanos: no século II d.C., é retomado o esquema "republicano" das basílicas do Fórum Romano (sem as êxedras ou absides. Fig. 17).

\section{Conclusão}

O Fórum de Trajano, então, seguindo uma "evolução" cronológica e arquitetônica dos fóruns imperiais, possuía claros elementos helenísticos, que delimitavam e isolavam sua area quadrangular por meio de pórticos, com uma entrada monumental através da Basílica Ulpia.

A colocação de uma basílica em um dos lados mais estreitos do fórum, tornando-a parte integrante dos pórticos e fazendo contraponto com a área sacra - do templo - apareceu nas colônias e nas províncias antes de surgir em Roma, onde, com o Fórum de Trajano, atinge um, senão o mais, alto grau de sofisticação e elaboração arquitetônicas para, então, retornar às províncias como o "exemplo canônico". Isto não impediu, porém, a existência de tipos basilicais que retomassem modelos arquitetônicos mais antigos, ditos "republicanos", sem êxedras, como aconteceu em Augst.

Quando se trata do trabalho arqueológico, as "certezas" de hoje podem mudar com novas

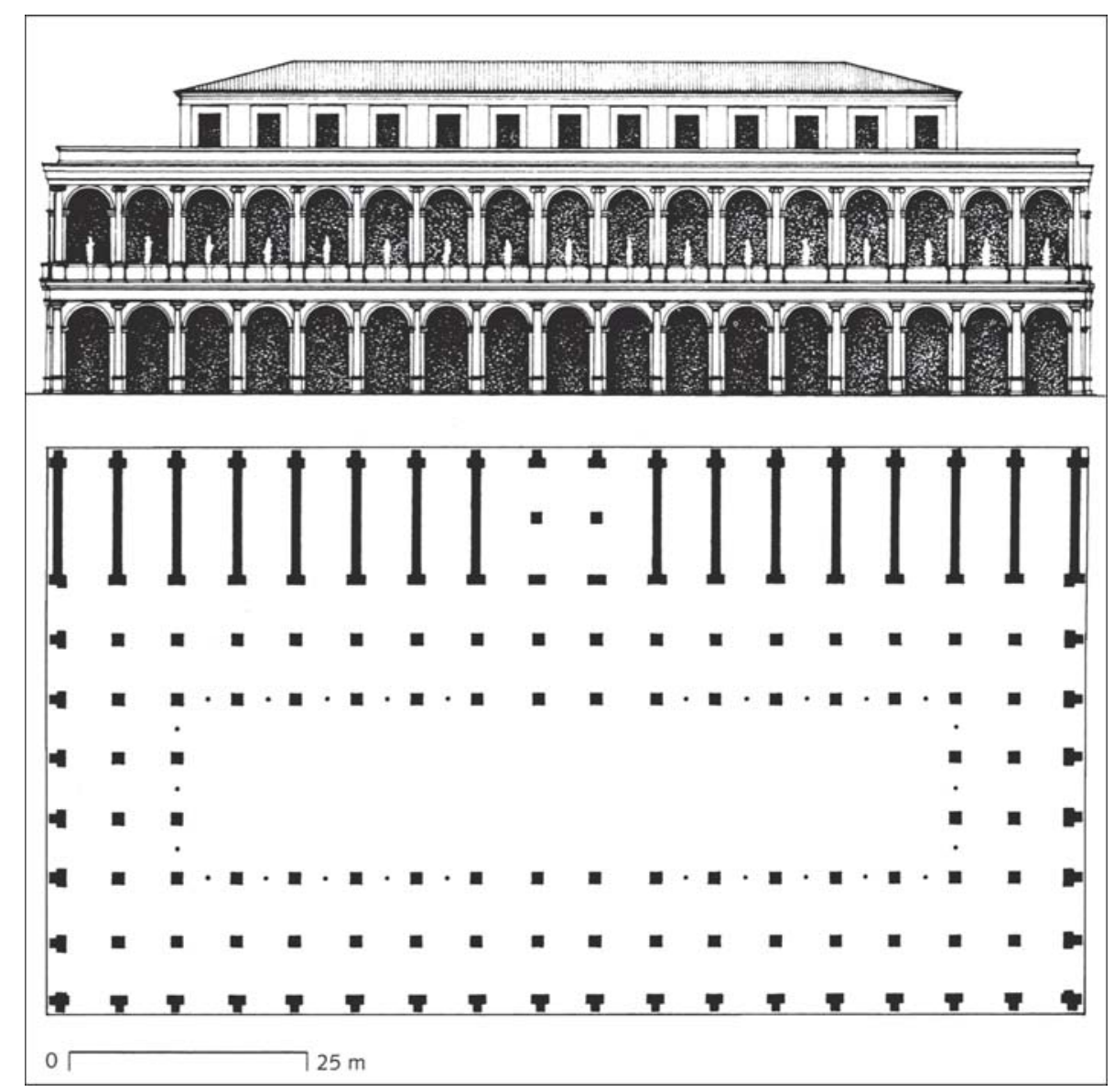

Fig. 17. Basílica Júlia. Argan (2003: 173). 
descobertas ou a reinterpretação de antigas evidências a qualquer momento, tornando-se "equívocos" interpretativos. Isto é natural e esperado em Arqueologia. O Fórum de Trajano é um claro exemplo disso. Mas ele é, principalmente, um exemplo de como a informação todo o tipo de informação: a língua, a religião, a arquitetura, as artes, a política etc. - circulava por todo o Império romano, em um processo circular e concêntrico ao mesmo tempo. Roma era o centro, importando e exportando constantemente a informação; mas a informação também circulava por "caminhos alternativos", extra e intra-provincialmente.

SANTOS, I.D. The provincial origin of the Trajan's Forum. Revista do Museu de Arqueologia e Etnologia, São Paulo, 18: 259-278, 2008.

Abstract: The Trajan's Forum has always been considered the 'high point' of the development of the Roman fora. The last of the Imperial Fora built in the centre of the Vrbs, during centuries it caused admiration to the visitors of the city, even when Rome was any more the capital of the Empire. Until some decades the scholars have considered it as the model for the provincial fora, specially in the European Occident. Nevertheless more recent works brought to light instances of contemporary canonic (tri-divided) fora or even elder than Trajan's, putting down the notion that this kind of fora arose at Rome and then spread to the Empire. Actually it was a model, but not an initial one; it was indeed the highest degree of the canonic fora, the model followed in many provinces as from the $2^{\text {nd }}$ century.

Keywords: Roman Fora - Trajan's Forum - Western Provincial Fora - Basilica Ulpia - Roman building model.

\section{Referências bibliográficas}

AMICI, C.M.

1982 Foro di Traiano: Basilica Ulpia e Biblioteche. Roma; Spoleto: Commissione Archeologica Comunale in Roma (BCAR.).

ARGAN, G.C.

2003 Da Antigüidade a Duccio. Trad. V. De Katinszky. São Paulo: Cosac \& Naify (História da arte italiana, v. 1).

BALTY, J.-C.

1991 Curia Ordinis. Recherches d'architecture et d'urbanisme antiques sur les curies provinciales du monde romain. Bruxelles: Palais des Académies. Académie Royale de Belgique. Mémoires de la Classe des Beaux-Arts (Collection in-4 $4^{\circ}-2^{\mathrm{e}}$ série, T. XV - fascicule 2 ).

\section{CARNABUCI, E.}

1996 I Luoghi dell'amministrazione della Giustizia nel Foro di Augusto. Nápoles: Jovene
Editore; Istituto Adriatico per la Storia del Principato fra Adriano e Diocleziano (I.A.S.P.A.D.), v. 2.

CAVALIERI, M.

2002 Auctoritas Aedificiorum. Sperimentazioni urbanistiche nei complessi forum-basilica delle Tres Galliae et Narbonensis durante i primi tre secoli dell'impero. Parma: Università di Parma - Istituto di Storia dell'Arte (Quaderni del seminário di archeologia; diretti da Arturo Carlo Quintavalle, v. 21).

CHAISEMARTIN, N. de

2003 Rome. Paysage urbain et idéologie. Des Scipions à Hadrien (II s. av.J.-C. - II s. ap. J.C.). Paris: Armand Colin (Collection U - Histoire).

CLARIDGE, A.

1998 Rome. An Oxford Archaeological Guide. 
Whith contributions by J. Toms and T. Cobberley. Oxford: Oxford University Press (General Editor: Barry Cunliffe).

2007 Hadrian's lost Temple of Trajan. Journal of Roman Archaeology, 20 (1): 54-94.

COARELLI, F.

2003 Roma. 3.ed. Roma-Bari: Laterza (Guide Archeologiche, 6).

CONNOLLY, P.; DODGE, H.

1998 The Ancien City. Life in Classical Athens \& Rome. Oxford: Oxford University Press.

FAVRO, D.G.

1996 The Urban Image of Augustan Rome. Cambridge: Cambrigde University Press.

GRENIER, A.

1958 Manuel d'Archéologie Gallo-Romaine: III.1. L'Arquitecrure - Notions préliminaires. L'Urbanisme - Les monuments de la vie politique: Capitole, Forum, Temple, Basilique. Paris: Picard.

GROS, P.

2000 La "militarisation" de l'urbanisme trajanian à la lumière des recherches récents sur le Forum Traiani. In: Gonzáles Fernández, J. (Coord.) Trajano emperador de Roma. Roma: L'Erma di Bretschneider: 227-250

2002 L'Architecture Romaine: du début du III ${ }^{\mathrm{e}}$ siècle av. J.-C. à la fin du Haut-Empire. 1. Les monuments publiques. 2. ed. [Paris] Picard (Gérard Nicolini (dir.) - Les Manuels d'Art et d'Archéologie Antiques).

GROS, P.; TORELLI, M.

2007 Storia dell'Urbanistica. Il mondo romano. 9. ed. Roma; Bari: Laterza (Grandi Opere).

HOMO, L.

1971 Rome impériale et l'urbanisme dans l'Antiquité. Paris: Albin Michel; volume triple [1951] (L'évolution de l'humanité, 33).

\section{LA ROCCA}

2004 Templum diui Traiani et columna cochlis. In RömMitt 111 (2004) 193-238.

MIERSE, W.E.; WAGG, F.H.

1999 Occhos Ensayos Interpretativos sobre el Arte Romano. Suplemento 1, Revista do Museu de Arqueologia e Etnologia. São Paulo: Universidade de São Paulo.

MENEGHINI, R.

1996 Bullettino della Commissione Archeologica Comunale in Roma [BCAR], 97: 47-88.

2001 Il Foro di Traiano, Ricostruzione architettonica e analisi strutturale. MDAI (R), 108: 245-268.

PACKER, J.E.

1997 The Forum of Trajan in Rome. A Study of Monuments in Brief. Berkeley; Los Angeles; Oxford: University of California Press.

PACKER, J.E.; SARRING, K.L.

1993 Il Foro di Traiano. Archeo, VII (11), nov. 1992 (1993): 63-93.

RAEPSAET-CHARLIER, M.-T.; RAEPSAET, G.

1975 Gallia Belgica et Germania Inferior. Vingt-cinq années de recherches historiques et archéologiques. In: TEMPORINI, H.; HAASE, W. (Dir.) Aufstieg und Niedergang der Römischen Welt (ANRW), II. Principat; 4. Berlim e Nova York: Walter de Gruyter: 3-299.

RICHARDSON Jr., L.

1992 A New Topographical Dictionary of Ancient Rome. Baltimore e Londres: The Johns

SANTOS, I.D. Hopkins University Press.

2006 A Basilica como elemento de Romanização da Gallia Comata no período de dominação romana. Dissertação de mestrado. São Paulo, Museu de Arqueologia e Etnologia da Universidade de São Paulo.

VIRLOUVET, C.

1985 Il Foro di Traiano. In: École Française de Rome. Roma Antiqua: l'area archeologica centrale: "Envois" degli architetti francesi (17811924), catálogo da exposição. Roma: 152-207.

WARD-PERKINS, J.

1981 Roman imperial Architecture. Harmondsworth: Penguin Books.

ZANKER, P.

1970 Das Trajansforum in Rom. Archäologischer Anzeiger: 499-544.

1992 Augusto y el poder de las imágines. Trad. P. Diener Ojeda; rev. técnica W. Tullmich. Madri: Alianza.

2000 The city as symbol: Rome and the creation of an urban image. In Fentress, E. (Ed.) Romanization and the City: Creation, Transformations, and Failures. Proceedings of a conference held at the American Academy in Rome to celebrate the $50^{\text {th }}$ anniversary of the excavations at Cosa, 14-16 May, 1998. Portsmouth, Rhode Island. Journal of Roman Archaeology; supplementary series, 38: 25-41. 